\title{
An analysis of selected factors influencing the efficacy of psoriasis therapy
}

\section{Analiza wybranych czynników wpływających na efektywność terapii łuszczycy}

\author{
Beniamin O. Grabarek',2, Jakub Krzaczyński³, Barbara Strzałka-Mrozik³, Dominika Wcisło-Dziadecka ${ }^{4}$
}

'Department of Histology, Cytophysiology and Embryology, Faculty of Medicine, University of Technology, Zabrze, Poland ${ }^{2}$ Center of Oncology, M. Skłodowska-Curie Memorial Institute, Krakow Branch, Poland

${ }^{3}$ Department of Molecular Biology, Faculty of Pharmaceutical Sciences in Sosnowiec, Medical University of Silesia in Katowice, Poland

${ }^{4}$ Department of Cosmetology, Faculty of Pharmaceutical Sciences in Sosnowiec, Medical University of Silesia in Katowice, Poland

'Katedra Histologii, Cytofizjologii i Embriologii, Wydział Nauk Medycznych im. Profesora Zbigniewa Religi,

Wyższa Szkoła Techniczna, Zabrze, Polska

2Narodowy Instytut Onkologii im. Marii Skłodowskiej-Curie, Państwowy Instytut Badawczy, Oddział w Krakowie, Polska

${ }^{3}$ Katedra i Zakład Biologii Molekularnej, Wydział Nauk Farmaceutycznych w Sosnowcu, Śląski Uniwersytet Medyczny w Katowicach, Polska

${ }^{4}$ Katedra Kosmetologii, Wydział Nauk Farmaceutycznych w Sosnowcu, Śląski Uniwersytet Medyczny w Katowicach, Polska

Dermatol Rev/Przegl Dermatol 2019, 106, 603-614

DOI: https://doi.org/l0.5।|4/dr.2019.92733

\section{CORRESPONDING AUTHOR/ ADRES DO KORESPONDENCJI:} dr n. med. Beniamin O. Grabarek Katedra Histologii, Cytofizjologii i Embriologii Wydział Nauk Medycznych im. Profesora Zbigniewa Religi w Zabrzu

Wyższa Szkoła Techniczna

Park Hutniczy 3-5

41-800 Zabrze, Polska

Narodowy Instytut Onkologii im. Marii Skłodowskiej-Curie Państwowy Instytut Badawczy Oddział w Krakowie

ul. Garncarska 11

31-115 Kraków, Polska

tel.: +48323641022

e-mail: bgrabarek7@gmail.com

\begin{abstract}
Psoriasis is a chronic disease characterized by a complex immunopathogenesis of recurrent inflammation of the skin. The course and intensity of the disease depend on many genetic, environmental and behavioural factors. The treatment of psoriasis includes a therapy with ultraviolet radiation, methotrexate, cyclosporine A, keratolytic preparations, tar, anthralin, glucocorticoids, calcineurin inhibitors, retinoids, and vitamin $\mathrm{D}_{3}$ derivatives. A new class of biological drugs (personalized therapy) that was introduced includes cytokine inhibitors, i.e. TNF - etanercept, adalimumab, infliximab, certolizumab pegol, golimumab; IL-12/23 ustekinumab; IL-17 - secukinumab, ixekizumab, brodalumab. Effective treatment of psoriasis is a challenge. It is an important matter in anticytokine therapy to determine the influence of factors such as age, sex, environmental factors, viral and bacterial infections, an occurrence of comorbidities, individual rate of drug metabolism, and pharmacologic interactions of additionally taken drugs. The influence of many different factors translates into obtaining a heterogeneous adequate response to molecularly targeted treatments.
\end{abstract}

\section{STRESZCZENIE}

Łuszczyca jest przewlekłą, nawracającą chorobą zapalną skóry, charakteryzującą się złożoną immunopatogenezą. Przebieg i nasilenie choroby zależą m.in. od czynników genetycznych, środowiskowych i behawioralnych. Łuszczyca istotnie wpływa na komfort i jakość życia pacjenta. Terapia opiera się na różnych strategiach, takich jak leczenie promieniowaniem ultrafioletowym, metotreksatem, cyklosporyną $A$, preparatami keratolitycznymi, dziegciem, antraliną, glikokortykosteroidami, inhibitorami kalcyneuryny, retinoidami i pochodnymi witaminy $\mathrm{D}_{3}$. Do nowej klasy leków biologicznych (terapia spersonalizowana) zalicza się inhibitory TNF - etanercept, adalimumab, infliksymab, certolizumab pegol, golimumab; IL-12/23 - ustekinumab; IL-17 - seku- 
kinumab, iksekizumab, brodalumab. Ponieważ efektywne leczenie łuszczycy stanowi wyzwanie, ważnym problemem $\mathrm{w}$ terapii antycytokinowej jest określenie wpływu takich czynników, jak wiek, płeć, czynniki środowiskowe, infekcje wirusowe, bakteryjne, choroby współwystępujące, indywidualne tempo metabolizowania leku, interakcje farmakologiczno-farmakokinetyczne dodatkowo przyjmowanych leków. Wpływ tak wielu różnorodnych czynników przekłada się na uzyskanie niejednorodnej, adekwatnej odpowiedzi na leczenie ukierunkowane molekularnie.

Key words: pharmacotherapy of psoriasis, personalized therapy, individual factor.

Słowa kluczowe: farmakoterapia łuszczycy, terapia spersonalizowana, czynnik osobniczy.

\section{INTRODUCTION}

Psoriasis is an inflammatory chronic and recurrent skin disease, which has two morbidity peaks: between the age of 20 and 30, and between the age of 50 and 60 .

The disease onset and course depend mainly on genetic, behavioural and environmental factors. The likelihood of children developing psoriasis in higher than $40 \%$ when both their parents suffer from psoriasis, and decreases to $14 \%$ when one parent is affected. Furthermore, a higher incidence risk of psoriasis in monozygotic twins (40\%) and dizygotic twins (10\%) was observed. Then, it is indicated that HLA-CW6 is a basic allele for the risk of psoriasis in the Caucasian population. Factors that may initiate the appearance of erythematous and exfoliating lesions include extreme psychical stress, severe infection - especially infections caused by Streptococcus sp. - injuries, surgical procedures, smoking, alcoholism, hormonal changes, and taking some drugs [1].

Psoriatic patients' quality of life is assessed by the following clinical indexes: Dermatology Life Quality Index (DLQI), Dermatology Quality of Life Scale (DQOLS), Psoriasis Disability Index (PDI), Impact of Psoriasis Questionnaire (IPSO), Psoriasis Index of Quality of Life (PSORIQOL), Beck Depression Inventory (BDI), Psoriasis Life Stress Inventory (PLSI), Questionnaire on Experience with Skin Complaints (QES), Short Form 36 Health Survey (SF-36), Subjective Well Being Scale (SWLS), and EuroQoL 5D (EQ-5D). On their basis it is possible to monitor the extent to which the disease makes daily life of patients difficult [2-4].

Plaque psoriasis (also known as psoriasis vulgaris) is the most common clinical type that constitutes about $85 \%$ of cases. It is characterized by

\section{WPROWADZENIE}

Łuszczyca to zapalna, przewlekła i nawracająca choroba skóry, w której przebiegu wyróżnia się dwa szczyty zachorowań: między 20. a 30. rokiem życia oraz między 50. a 60 . rokiem życia.

Początek i przebieg choroby zależą przede wszystkim od czynników genetycznych, behawioralnych i środowiskowych. Prawdopodobieństwo wystąpienia łuszczycy u potomstwa jest większe niż $40 \%$, gdy oboje rodzice chorują na łuszczycę, i zmniejsza się do $14 \%$, gdy tylko jedno z rodziców choruje. Ponadto zaobserwowano zwiększone ryzyko wystąpienia łuszczycy u bliźniąt jednojajowych (ryzyko 40\%) oraz dwujajowych (ryzyko $10 \%)$. Wskazuje się również, że HLA-CW6 to podstawowy allel ryzyka wystąpienia łuszczycy dla populacji kaukaskiej. Czynnikiem zapoczątkowującym wystąpienie zmian rumieniowo-złuszczających może być bardzo silny stres psychiczny, ostra infekcja, zwłaszcza zakażenia wywołane przez Streptococcus sp., uraz, zabieg chirurgiczny, palenie papierosów, alkoholizm, zmiany hormonalne i zażywanie niektórych leków [1].

Jakość życia pacjentów z łuszczycą określa się za pomocą następujących wskaźników klinicznych: DLQI (Dermatology Life Quality Index), DQOLS (Dermatology Quality of Life Scale), PDI (Psoriasis Disability Index), IPSO (Impact of Psoriasis Questionnaire), PSORIQOL (Psoriasis Index of Quality of Life), BDI (Beck Depression Inventory), PLSI (Psoriasis Life Stress Inventory), QES (Questionnaire on Experience with Skin Complaints), SF-36 (Short Form 36 Health Survey), SWLS (Subjective Well Being Scale), EQ-5D (EuroQoL 5D). Na ich podstawie można monitorować, $\mathrm{w}$ jak dużym stopniu choroba utrudnia pacjentowi wykonywanie codziennych czynności [2-4].

Łuszczyca plackowata (znana również jako łuszczyca zwykła) jest najczęstszym wariantem klinicznym, stanowiącym około 85\% przypadków. Charakteryzuje się grubą, rumieniową grudką, która jest pokryta 

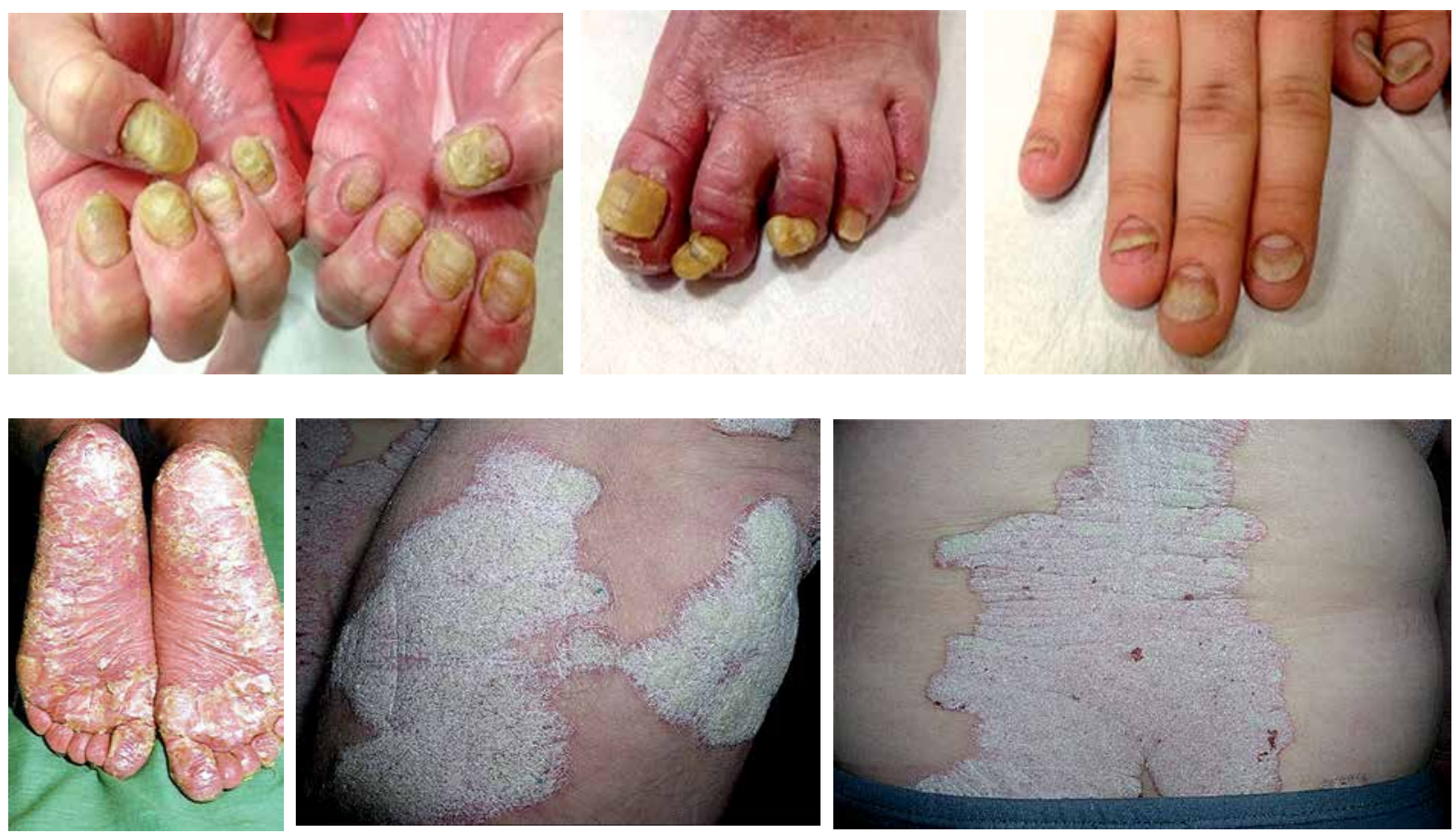

Figure I. Examples of lesions observed in psoriasis

Rycina I. Przykładowe zmiany obserwowane w łuszczycy

thick erythematous papulae that are covered in silvery scales and most commonly found on the knees, elbows, scalp, and torso [5].

Clinical lesions are histologically reflected as epidermal hyperplasia, parakeratosis, hypogranulosis, neutrophil and lymphocyte infiltration in the epidermis and dermis, as well as dilated blood vessels [6]. Other clinical subtypes of psoriasis include: pustular psoriasis of hands and feet, generalized pustular psoriasis, nail psoriasis, erythrodermic psoriasis, and psoriatic arthritis [4].

Figure 1 presents sample psoriatic lesions. Upon being admitted to the Ward, every patient provided their voluntary consent to be photographed and have their photographs used.

It should also be remembered that psoriasis might be concomitant with systemic metabolic diseases (arterial hypertension, ischaemic heart disease, diabetes, obesity, hyperlipidaemia, metabolic syndrome) that contribute to an increased risk for stroke, chronic renal insufficiency, as well as mood disorders, and consequently, exert a negative influence on the lifetime of psoriatic patients [5].

\section{MOLECULAR BACKGROUND OF PSORIASIS, ITS SYMPTOMS AND THERAPEUTIC STRATEGIES}

Molecularly, psoriasis manifests itself with a change in cytokine concentration, mainly interleu- srebrzystymi łuskami blaszkowatymi, preferencyjnie zlokalizowanymi na powierzchniach prostowników, skórze głowy i tułowiu [5].

Histologicznym odzwierciedleniem zmian klinicznych jest rozrost naskórka, parakeratoza, hipogranuloza, naciek neutrofilów i limfocytów w naskórku i skórze właściwej oraz rozszerzone naczynia krwionośne [6]. Inne kliniczne podtypy łuszczycy to: łuszczyca krostkowa dłoni i stóp, łuszczyca krostkowa uogólniona, łuszczyca paznokci, postać erytrodermiczna oraz łuszczycowe zapalenie stawów [4].

Na rycinie 1 przedstawiono przykładowe zmiany w przebiegu łuszczycy. Przy przyjęciu na oddział od każdego pacjenta uzyskano dobrowolną zgodę na wykonanie i wykorzystanie zdjęć.

Należy pamiętać o współwystępowaniu z łuszczycą układowych chorób metabolicznych (nadciśnienie tętnicze, choroba niedokrwienna serca, cukrzyca, otyłość, hiperlipidemia, zespół metaboliczny), które przyczyniają się do zwiększonego ryzyka wystąpienia udaru, przewlekłej niewydolności nerek i zaburzeń nastroju, co negatywnie wpływa na długość życia chorych na łuszczycę [5].

\section{MOLEKULARNE PODŁOŻE ŁUSZCZYCY, JEJ OBJAWY ORAZ STRATEGIE TERAPEUTYCZNE}

Na poziomie molekularnym łuszczyca objawia się zmianą stężeń cytokin, głównie interleukin (IL) - IL-12, 
kins (IL) - IL-12, IL-23, IL-17, IL-22 - tumour necrosis factor (TNF), interferon $\gamma(\mathrm{IFN}-\gamma)$, and transforming growth factor $\beta 1-3$ (TGF- $\beta 1-3)$ [6, 7].

IL-12 and IL-23 are heterodimeric cytokines that are characterized by pleiotropic effects. These interleukins are composed of two subunits $(\mathrm{p})$ : it is p35 and p40 for IL-12, and p19 and p40 for IL-23. IL-12/ 23 is, first and foremost, expressed by antigen-presenting cells, macrophages, fibroblasts, and keratinocytes. By binding to specific cell membrane receptors - IL12 $\beta R 1$, IL12 $\beta R 2$, and IL23R - they induce the JAK/STAT signalling pathway, and consequently increased the secretion of TNF, IFN- $\gamma$, IL-17, among others [8].

IL-12 plays a key role in initiating and maintaining immune response in which Th1 lymphocyte subpopulation is engaged that is characterized by an ability to secrete, first and foremost, TNF and IFN- $\gamma$ [9]. Then, having bonded with IL-23R, IL-23 induces changes in expression profile of IL-17A, IL-17F, IL-21, IL-22, IL-26, and granulocyte-macrophage colony-stimulating factor (GM-CSF). Both IL- 6 and TGF- $\beta$ play a significant role in transformation of naive Th0 lymphocytes into Th17 phenotype [10]. Biological activity of IL-17 is associated with signalling pathways dependent on nuclear factor $\mathrm{\kappa B}(\mathrm{NF}-\mathrm{\kappa B})$, and mitogen-activated protein kinases (MAPKs). In addition, IL-36 stimulates production of IL-6, IL-23 and IL-8, and intensifies IL-17 secretion by Th17 cells [11].

TNF is also an important cytokine in induction and development of psoriatic lesions since it causes specific biological effects by interacting with TNFR1 and TNFR2 [12]. Bonding of TNF and TNFR1 leads to a start of caspase and MAPK pathways, what results in directing cells onto the apoptotic pathway. Then, TNF-TNFR2 interaction contributes to NF- $\kappa B$ activation and increase in cell proliferation [13].

The third subpopulation of T helper lymphocytes that is associated with psoriasis is Th22lymphocyte subpopulation; the influence of IL-6, TNF and dendritic cells on the population of naïve Th0 lymphocytes contributes to the creation of the latter. An existence of close secretion connection among IL-17: IL-22: IL-23 what results in creation of IL-12/Th1; IL-23/Th17; IL-22/Th22 axis is indicated. An occurrence of correlations between signalling pathways, loss of balance between the concentration profile of pro- and anti-inflammatory cytokines, is the reason behind the complex pathogenesis of this dermatosis and difficulties in obtaining an adequate response to applied treatment [14].

Consequences of excessive and uncontrolled activation of the immune system in psoriasis are skin lesions. Moreover, leucocyte migration to the inflamed tissue is facilitated by microvasculature
IL-23, IL-17, IL-22, czynnika martwicy nowotworu (TNF), interferonu $\gamma($ IFN- $\gamma$ ) i transformującego czynnika wzrostu $\beta 1-3$ (TGF- $\beta 1-3)[6,7]$.

IL-12 i IL-23 są heterodimerycznymi cytokinami, które cechuje plejotropizm działania. W budowie tych interleukin wyróżnia się dwie podjednostki (p), dla IL-12: p35, p40, a dla IL-23: p19, p40. IL-12/23 są przede wszystkim eksprymowane przez komórki prezentujące antygen, makrofagi, fibroblasty, keratynocyty. Poprzez związanie ze swoistymi receptorami

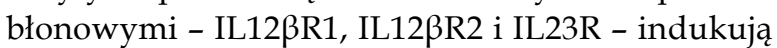
ścieżkę sygnalizacyjną JAK/STAT, czego implikacją jest nasilenie sekrecji, m.in. TNF, IFN- $\gamma$, IL-17 [8].

IL-12 odgrywa ważną rolę w inicjowaniu i utrzymywaniu odpowiedzi immunologicznej, w którą zaangażowana jest subpopulacja limfocytów Th1, charakteryzujących się zdolnością sekrecji przede wszystkim TNF i IFN- $\gamma$ [9]. IL-23 po związaniu z receptorem IL-23R indukuje zmiany profilu ekspresji IL-17A, IL-17F, IL-21, IL-22, IL-26 i czynnika wzrostu kolonii makrofagów (GM-CSF). W przekształceniu naiwnych limfocytów Th0 do fenotypu Th17 istotną funkcję odgrywają wspólnie IL-6 i TGF- $\beta$ [10]. Biologiczna aktywność IL-17 wiąże się ze szlakami sygnalizacyjnymi zależnymi od jądrowego czynnika кB (NF-kB), a także kinaz aktywowanych mitogenami (MAPK). Ponadto IL-36 stymuluje wytwarzanie IL-6, IL-23 i IL-8 i wzmaga wydzielanie IL-17 przez komórki Th17 [11].

TNF jest ważną cytokiną w indukcji i rozwoju zmian łuszczycowych, która wywołuje określone efekty biologiczne poprzez oddziaływanie $\mathrm{z}$ receptorami TNFR1 i TNFR2 [12]. Związanie TNF z receptorem TNFR1 prowadzi do uruchomienia szlaku kaspaz i MAPK, czego wynikiem jest ukierunkowanie komórek na szlak apoptozy. Interakcja TNF-TNFR2 przyczynia się do aktywacji NF-kB i wzmożenia proliferacji komórek [13].

Trzecią subpopulacją limfocytów T pomocniczych związanych z łuszczycą jest subpopulacja limfocytów Th22, do której powstania przyczynia się oddziaływanie IL-6, TNF i komórek dendrytycznych na populację naiwnych limfocytów Th0. Wskazuje się na występowanie ścisłej zależności między sekrecją IL-17, IL-22 i IL-23, co skutkuje wytworzeniem osi IL-12/Th1, IL-23/Th17, IL-22/Th22. Występowanie współzależności między szlakami sygnalizacyjnymi, utrata równowagi pomiędzy profilem stężeń cytokin o działaniu pro- i przeciwzapalnym stanowi przyczynę złożonej immunopatogenezy tej dermatozy i trudności w uzyskaniu adekwatnej odpowiedzi na stosowane leczenie [14].

Konsekwencją nadmiernej i niekontrolowanej aktywacji układu odpornościowego w przebiegu łuszczycy są zmiany skórne. Ponadto migracja leukocytów do zmienionej zapalnie tkanki jest ułatwiona poprzez występujące mikrounaczynienie w łuszczycy, które charakteryzuje się krętymi i nieszczelnymi naczyniami krwionośnymi [8]. 
present in psoriasis that is characterized by winding and porous blood vessels [8].

In typical cases, the diagnosis is made by assessing skin lesion morphology and characteristic sites for eruptions (the scalp, areas above joints, sacral region). In case of doubt, it is recommended to perform a skin biopsy from the lesion and a histopathological examination to confirm the diagnosis [1].

According to the guidelines of Polish Dermatological Society, topical preparations are used in treatment of mild psoriasis. The following are recommended for plaque psoriasis: keratolytic preparations, cignolin, tar, topical glucocorticoids, vitamin $\mathrm{D}_{3}$ derivatives, retinoids, calcineurin inhibitors, and combination preparations (calcipotriol/betamethasone dipropionate). In case of psoriasis of the scalp it is indicated to use: a combination of calcipotriol with betamethasone dipropionate, topical glucocorticoids with moderate and strong effect, tar, cignolin alcoholic extract and tazarotene. Then, vitamin A and $\mathrm{D}_{3}$ derivatives, calcineurin inhibitors, and topical glucocorticoids are recommended for psoriasis affecting the face, and inverse psoriasis.

For psoriasis of hands and feet it is recommended to use therapies including keratolytic drugs, potent glucocorticoids in combination with keratolytic drugs, vitamin $\mathrm{D}_{3}$ derivatives in combination with potent glucocorticoids, tar in combination with glucocorticoids and keratolytic drugs, PUVA/UVB topical therapy, an excimer laser in combination with topical treatment and cyclosporine A, methotrexate, acitretin, dimethyl fumarate, biological drugs in case of severe lesions and also when topical treatment and/or combination treatment fail.

In case of moderate and severe lesions the treatment including the following is recommended: phototherapy, photochemotherapy, classic anti-psoriatic drugs (methotrexate, cyclosporine A, acitretin), new micromolecular substances (apremilast, dimethyl fumarate), and biological drugs $[15,16]$.

At present, it is believed that hyperproliferation of epidermal cells, which has earlier been believed to be the cause of the disease, is a consequence of inflammation mediated by $\mathrm{T}$ lymphocytes. Basing on these etiopathogenetic mechanisms and experience in treatment of other immune diseases in rheumatology and gastroenterology, clinical studies on introducing biological drugs (anti-cytokine) into the treatment of psoriasis were initiated [17].

An effective anti-cytokine treatment for psoriasis is associated with persistent blocking of cytokine effects that play an important role in its induction and development. According to the recommendations of Polish Dermatological Society, this type of therapy is used in moderate and severe psoriasis [16]. This drug group is characterized by unique specificity
Rozpoznanie w typowych przypadkach opiera się na ocenie morfologii zmian skórnych oraz charakterystycznego umiejscowienia wykwitów (owłosiona skóra głowy, okolice nad stawami, okolica krzyżowa). W przypadku wątpliwości co do słuszności rozpoznania klinicznego wskazana jest biopsja skóry ze zmiany chorobowej i badanie histopatologiczne [1].

Zgodnie z rekomendacjami Polskiego Towarzystwa Dermatologicznego w terapii łuszczycy o niewielkim nasileniu stosuje się preparaty miejscowe. $W$ przypadku łuszczycy plackowatej zaleca się: preparaty keratolityczne, cygnolinę, dziegcie, miejscowe glikokortykosteroidy, pochodne witaminy $\mathrm{D}_{3^{\prime}}$, retinoidy, inhibitory kalcyneuryny, preparaty złożone (kalcypotriol/dipropionian betametazonu). U pacjentów z łuszczycą owłosionej skóry głowy wskazane jest zastosowanie: połączenia kalcypotriolu z dipropionianem betametazonu, miejscowych glikokortykosteroidów o umiarkowanym i silnym działaniu, dziegci, spirytusu cygnolinowego, tazarotenu.

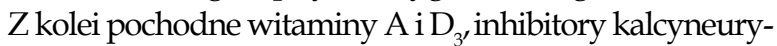
ny, miejscowe glikokortykosteroidy są rekomendowane w przypadkach łuszczycy twarzy i łuszczycy odwróconej.

W leczeniu łuszczycy rąk i stóp zaleca się terapie z wykorzystaniem leków keratolitycznych, silnych glikokortykosteroidów w połączeniu z lekami keratolitycznymi, pochodnych witaminy $\mathrm{D}_{3} \mathrm{w}$ połączeniu z silnymi glikokortykosteroidami, dziegci w połączeniu z glikokortykosteroidami i lekami keratolitycznymi, miejscowej terapii PUVA/UVB, lasera ekscymerowego w skojarzeniu z leczeniem miejscowym oraz cyklosporyny A, metotreksatu, acytretyny, dimetylanu fumaranu, leków biologicznych przy dużym nasileniu zmian, a także w razie niepowodzenia leczenia miejscowego i/lub leczenia skojarzonego.

W przypadku umiarkowanego i dużego nasilenia zmian rekomendowane jest leczenie oparte na fototerapii, fotochemioterapii, klasycznych lekach przeciwłuszczycowych (metotreksat, cyklosporyna A, acytretyna), nowych substancjach drobnocząsteczkowych (apremilast, fumaran dimetylu) oraz lekach biologicznych [15, 16].

Obecnie uważa się, że hiperproliferacja komórek naskórka, która była wcześniej uważana za przyczynę choroby, jest skutkiem procesu zapalnego, w którym pośredniczą limfocyty T. Opierając się na tych mechanizmach etiopatogenetycznych i doświadczeniach z leczenia innych chorób immunologicznych w reumatologii i gastroenterologii, rozpoczęto badania kliniczne dotyczące włączenia do leczenia łuszczycy leków biologicznych (antycytokinowych) [17].

Efektywna terapia przeciwcytokinowa łuszczycy wiąże się z trwałym blokowaniem aktywności cytokin pełniących istotną funkcję $\mathrm{w}$ jej indukcji i rozwoju. Zgodnie z rekomendacjami Polskiego Towarzystwa Dermatologicznego ten rodzaj terapii stosuje się w umiarkowanej i ciężkiej postaci łuszczycy [16]. Grupa leków stosowanych w tym przypadku charakteryzuje się unikatową 
with regard to proinflammatory factor and fast as well as long-lasting treatment effects $[18,19]$.

Currently, it is possible to distinguish between several characterized anti-cytokine drug groups used in the treatment of psoriasis: TNF inhibitors etanercept, adalimumab, infliksymab, certolizumab pegol, golimumab; anti-IL-17 drugs - secukinumab, ixekizumab, brodalumab; and an anti-IL-12/23 drug - ustekinumab [19]. Certolizumab pegol is the only TNF inhibitor conjugated with polyethylene glycol that as opposed to other anti-TNF drugs does not have the Fc fragment, and thus, does not induce cytotoxicity dependent on antibodies, complement activation or apoptosis in T cells or macrophages [20].

An integral part of the personalized medicine concept, defined as "precise medicine," is the use of molecular biomarkers, thanks to which it is possible to detect occurrence of adverse reactions of drugs or loss of cell sensitivity to treatment at an early stage [21]. Such an approach gains in popularity since molecular changes precede phenotype changes [22, 23]. Therefore, when effective treatment of psoriasis is concerned, it seems important to recognize and characterize factors that could influence the efficacy of a chosen therapeutic strategy.

\section{FACTORS INFLUENCING THE EFFICACY OF PSORIASIS TREATMENT}

Factors that may exert an influence on the efficacy of psoriasis treatment and/or possibility of improving the treatment efficacy have been presented in table 1 . swoistością pod względem czynnika prozapalnego oraz szybkim i długotrwałym efektem działania $[18,19]$.

Obecnie można wyróżnić kilka dobrze scharakteryzowanych grup leków antycytokinowych wykorzystywanych w terapii łuszczycy: inhibitory TNF - etanercept, adalimumab, infliksymab, certolizumab pegol, golimumab, leki anty-IL-17 - sekukinumab, iksekizumab, brodalumab, oraz lek anty-IL-12/23 - ustekinumab [19]. Certolizumab pegol to jedyny inhibitor TNF skoniungowany z glikolem polietylenowym, który w przeciwieństwie do innych leków anty-TNF nie ma fragmentu ulegającego fragmentacji $(\mathrm{Fc})$, czyli nie indukuje cytotoksyczności zależnej od przeciwciał, aktywacji dopełniacza lub apoptozy w komórkach T lub makrofagach [20].

Integralną częścią koncepcji medycyny spersonalizowanej, określanej też jako medycyna precyzyjna, jest zastosowanie biomarkerów molekularnych, dzięki którym na wczesnym etapie można wykryć wystąpienie działań niepożądanych leków lub też utratę wrażliwości komórek na leczenie [21]. Takie podejście zyskuje na znaczeniu, gdyż zmiany molekularne wyprzedzają zmiany fenotypowe $[22,23]$. Istotnym zagadnieniem $z$ punktu widzenia efektywności terapii łuszczycy jest poznanie i scharakteryzowanie czynników, które mogą wpływać na powodzenie wybranej strategii terapeutycznej.

\section{CZYNNIKI WPŁYWAJACCE NA SKUTECZNOŚĆ LECZENIA ŁUSZCZYCY}

Czynniki, które mają wpływ na efektywność terapii łuszczycy i/lub możliwości poprawy jej skuteczności, przedstawiono $\mathrm{w}$ tabeli 1.

Table I. List of selected factors influencing the efficacy of psoriasis pharmacotherapy and/or the possibility of improving the efficacy of treatment Tabela I. Lista wybranych czynników wpływających na efektywność farmakoterapii łuszczycy i/lub możliwość poprawy skuteczności leczenia

Intensity of psoriatic lesions (mild, moderate, severe)/Stopień nasilenia zmian łuszczycowych (niewielki, umiarkowany, ciężki)

Genetic factors, e.g. mutations in PSORSI gene, HLACw6/Czynniki genetyczne, np. mutacje w genie PSORSI, HLACw6

Environmental factors, e.g. smoking, alcoholism/Czynniki środowiskowe, np. palenie papierosów, alkoholizm

Past infections, mainly caused by Streptococcus sp./Przebyte infekcje, głównie zakażenia wywołane przez Streptococcus sp.

Used drugs/Stosowane leki

Systemic metabolic diseases, such as: diabetes, overweight or obesity, metabolic syndrome, cardiovascular diseases/Układowe schorzenia metaboliczne, takie jak cukrzyca, nadwaga lub otyłość, zespół metaboliczny, choroby układu sercowo-naczyniowego

Social and economic status/Status społeczno-ekonomiczny

Injuries, surgical procedures/Urazy, zabiegi chirurgiczne

Psychophysiological disorders (mainly chronic considerable stress, unipolar and bipolar disorder)/Zaburzenia psychofizjologiczne (głównie chroniczny silny stres, zaburzenia jedno- i dwubiegunowe)

Co-operation between the patient and the physicianMspółpraca pacjenta z lekarzem

Availability of a given treatment form and financial burden placed on the patient/Dostępność danej formy leczenia i stopień obciążenia finansowego pacjenta

Lifestyle, physical activity, eating habits/Styl życia, aktywność fizyczna, nawyki żywieniowe

Polymorphism of genes engaged in drug biotransformation that plays a key role in induction and development of inflammation/ Polimorfizm genów zaangażowanych w biotransformację leków oraz odgrywających istotną rolę w indukcji i rozwoju stanu zapalnego Development of personalized medicine/Rozwój medycyny spersonalizowanej 
Viral and bacterial infections are one of the factors that influence the course of psoriasis. Given the immunosuppressive mechanism of the effects of drugs used in the psoriasis treatment, the patients are predisposed to recurrent infections caused mainly by Pneumocystis carinii, Nocardia sp., Listeria monocytogenes, Histoplasma capsulatum, Aspergillus sp., and Coccidioides immitis. A higher tendency to develop systemic metabolic diseases, HIV and HCV infections, and collagenoses is also observed in psoriatic patients [24-26].

It should be remembered that administration of some drugs to psoriatic patients contributes to appearance of disease exacerbation periods, and by the same token, it is necessary to reconsider the choice of the right treatment. These drugs include: antimalarial drugs, $\beta$-blockers, lithium, amiodarone, progesterone, acetylcholinesterase inhibitors, nonsteroidal anti-inflammatory drugs, and cimetidine [27].

Moreover, psoriatic patients are at increased risk for developing systemic metabolic diseases that contribute to exacerbation periods of the disease and influence the choice of proper therapeutic strategies [28, 29].

Bardazzi et al. show that during a therapy with cyclosporine A in patients whose body weight exceeds $90 \mathrm{~kg}$ it is necessary to set the drug dose individually [30]. Similar observations were made by Gisondi et al. who confirmed that the best response to cyclosporine A treatment was among those patients who decreased their body weight as a result of a low-calorie diet [31].

Then, Ricceri et al. assessed the safety of biological drugs, such as adalimumab, ustekinumab, etanercept, secukinumab, infliximab, golimumab, and certolizumab pegol in a group of 266 psoriatic patients including 164 (61.7\%) men and 102 (38.2\%) women with the mean age of $72.3 \pm 5.7$ (age range: $65-85 \mathrm{y} / \mathrm{o})$. They indicated the incidence of 25 adverse events during the observation, with infections being the most common ones ( $48 \%$ of the studied). Concluding, they draw attention to the fact that the incidence of adverse reaction in older patients was similar to the one observed in younger ones. Thus, age cannot be a factor that limits the choice of a therapeutic strategy [32].

Other factors that influence the treatment efficacy are patients' social and economic status, access to therapies, education, rules for financing treatments [33], and co-operation between the patient and the physician [34].

An analysis conducted by Choi et al. confirms the importance of the drug price, as well as rules for drug benefits and patient's co-payments in the choice and acceptance of the given therapeutic form. From among 30 individuals qualified for ustekinumab treatment, $82.4 \%$ of patients opted for an intermittent treatment with this drug, and $15.8 \%$ of patients chose a continu-
Na przebieg łuszczycy wpływają m.in. infekcje wirusowe i bakteryjne. Z uwagi na immunosupresyjny mechanizm działania leków wykorzystywanych w terapii łuszczycy chorzy są predysponowani do nawracających zakażeń spowodowanych głównie przez Pneumocystis carinii, Nocardia sp., Listeria monocytogenes, Histoplasma capsulatum, Aspergillus sp. i Coccidioides immitis. U pacjentów z łuszczycą obserwuje się również większą skłonność do występowania układowych chorób metabolicznych, zakażeń wirusem HIV, HCV oraz kolagenoz [24-26].

Warto pamiętać, że stosowanie niektórych leków przyczynia się do występowania zaostrzeń łuszczycy, w związku z czym konieczne jest powtórne rozważenie wyboru właściwego leczenia. Do tych leków zalicza się: leki przeciwmalaryczne, leki $\beta$-adrenolityczne, lit, amiodaron, progesteron, inhibitory acetylocholinesterazy, niesteroidowe leki przeciwzapalne i cymetydynę [27].

U pacjentów z łuszczycą podkreśla się też zwiększone ryzyko wystąpienia układowych chorób metabolicznych, które przyczyniają się do zaostrzeń choroby i mają wpływ na dobór strategii terapeutycznej $[28,29]$.

Bardazzi i wsp. wskazują, że podczas terapii cyklosporyną A u pacjentów, których masa ciała przekracza 90 kg, konieczny jest indywidualny dobór dawkowania leku [30]. Podobne obserwacje poczynili Gisondi i wsp., którzy stwierdzili lepszą odpowiedź na leczenie cyklosporyną A u tych chorych, którzy w wyniku stosowania niskokalorycznej diety zmniejszyli masę ciała [31].

Z kolei Ricceri i wsp. w grupie 266 pacjentów z łuszczycą, w tym 164 (61,7\%) mężczyzn i 102 (38,3\%) kobiet w wieku średnio 72,3 $\pm 5,7$ roku (przedział wiekowy 65-85 lat), ze stwierdzonymi chorobami współwystępującymi ocenili bezpieczeństwo stosowania następujących leków biologicznych: adalimumabu, ustekinumabu, etanerceptu, sekukinumabu, infliksymabu, golimumabu i certolizumabu pegol. Odnotowali oni wystąpienie 25 zdarzeń niepożądanych w okresie obserwacji, z których najczęstszym były infekcje (48\% badanych). W podsumowaniu zwracają uwagę, że częstość występowania działań niepożądanych u pacjentów w starszym wieku była zbliżona do obserwowanej u młodszych. Dlatego też wiek nie może stanowić czynnika ograniczającego wybór strategii terapeutycznych [32].

Kolejnymi czynnikami wpływającymi na skuteczność terapii są status społeczno-ekonomiczny chorych, dostęp do terapii, edukacja, zasady finansowania leczenia [33] oraz współpraca między pacjentem a lekarzem [34].

Analiza przeprowadzona przez Choi i wsp. potwierdza wpływ ceny leku oraz zasad jego refundacji i współpłacenia przez pacjenta na wybór i akceptację danej formy terapii. Spośród 30 osób zakwalifikowanych do leczenia ustekinumabem $82,4 \%$ pacjentów zdecydowało się na leczenie przerywane, a 15,8\% chorych wybrało ciągłą formę 52-tygodniowego leczenia. Badacze stwierdzili, że pacjenci, którzy pomimo oczekiwanych efektów 
ous 52-week-long treatment. The researchers concluded that patients who chose intermittent treatment with ustekinumab did that despite expected therapeutic results only due to the financial burden [35].

Then, on the basis of an original analysis Sizto et al. concluded that treatment with methotrexate and cyclosporine A is cost-effective, but requires monitoring with regard to toxicity. When it comes to biological drugs, only adalimumab was considered to be an economical option [36].

Economic factors continually exert an influence of the possibility of using specific therapies, determine their accessibility, and to some extent, co-decided on the appearance and length of remission periods. This issue remains current since Augustin et al. show that the most cost-effective 52-week-long therapy is the one that used secukinumab as compared with adalimum$\mathrm{ab}$, etanercept, infliximab, and ustekinumab [37].

Important factors that may influence the treatment efficacy are psychophysiological disorders observed in psoriatic patients. They indicate a correlation between the intensity of skin lesions and the patient's metal condition [38, 39]. Jin et al. observed that in a group of psoriatic patients with depression symptoms diagnosed before the pharmacotherapy the clinical response to etanercept treatment was worse as compared with patients with undiagnosed depression. They show that symptoms of depression constitute an independent prognostic factor of the response to treatment [40].

Furthermore, patients' lifestyle, physical activities and eating habits influence the efficacy of psoriasis treatment. It is recommended to decrease the body weight by means of low-calorie diet and exercises in patients with overweight and obesity, and vitamin $\mathrm{D}_{3}$ supplementation in case of its deficiency. Gluten-free diet should be considered only for patients with confirmed gluten intolerance [41, 42].

Next, genetic polymorphism plays a key role in obtaining adequate response to applied therapeutic strategy. With regards to psoriasis pharmacotherapy, the importance of the polymorphism of the following genes is emphasized: TNF, MTHR, SLC19A1, MTRR, CGH, ABCB1, VNTR, IL1B, IL1RN, KIR2DS2, KIR2DL2, CHST11, AMPD1, ITPA, MTHFD1, FCGR3A, BAFF-871, IL-6, as well as the following enzymatic protein-coding genes that participate in drug biotransformation: CYP39A1, CYP2D6, CYP1A2, CYP2D6, SLC22A2, SLC7A7, ALDH2 [43-45].

For instance, regarding CYP2D6, which plays an important role in psoriasis [46], it is showed that polymorphism of this gene determined the speed of drug metabolising. Consequently, individuals characterised by low pace of metabolising drugs, in which CYP2D6 participates, are to a greater extent exposed to side effects of the therapy due to a prolonged peri- terapeutycznych stosowali ustekinumab z przerwami, decydowali się na taką formę leczenia tylko ze względów ekonomicznych [35].

Sizto i wsp. na podstawie przeprowadzonej oceny stwierdzili, że leczenie metotreksatem i cyklosporyną A jest opłacalne, choć wymaga monitorowania pod kątem toksyczności. Wśród leków biologicznych za ekonomicznie uzasadnione uznali tylko stosowanie adalimumabu [36].

Czynnik ekonomiczny wpływa na możliwość stosowania określonych terapii, determinuje ich dostępność i w pewnym stopniu współdecyduje o uzyskaniu i długości okresu remisji. Temat ten jest wciąż niezwykle aktualny, gdyż Augustin i wsp. wskazują, że najbardziej opłacalną, trwającą 52 tygodnie terapią jest leczenie $\mathrm{z}$ wykorzystaniem sekukinumabu w porównaniu $\mathrm{z}$ adalimumabem, etanerceptem, infliksymabem i ustekinumabem [37].

Istotnym czynnikiem, który może wpływać na skuteczność leczenia, są zaburzenia psychofizjologiczne obserwowane u pacjentów z łuszczycą. Wskazuje się na współzależność pomiędzy nasileniem zmian skórnych a stanem psychicznym pacjenta [38, 39]. Jin i wsp. zaobserwowali, że u chorych z objawami depresji stwierdzonymi przed włączeniem farmakoterapii łuszczycy odpowiedź kliniczna na leczenie etanerceptem była gorsza w porównaniu z pacjentami, u których nie występowały takie objawy. Wskazują oni, że objawy depresji stanowią niezależny czynnik prognostyczny odpowiedzi na leczenie [40].

Na efektywność leczenia łuszczycy wpływają również styl życia, aktywność fizyczna oraz nawyki żywieniowe pacjentów. Pacjentom z nadwagą i otyłością zaleca się zmniejszenie masy ciała poprzez dietę niskokaloryczną i aktywność fizyczną. W razie niedoboru witaminy $\mathrm{D}_{3}$ rekomendowana jest suplementacja. Dieta bezglutenowa powinna być rozważana tylko u chorych z potwierdzoną nietolerancją glutenu $[41,42]$.

Poza tym polimorfizm genetyczny odgrywa niezmiernie ważną rolę w uzyskaniu adekwatnej odpowiedzi na stosowaną strategię terapeutyczną. W odniesieniu do farmakoterapii łuszczycy podkreśla się znaczenie polimorfizmu genów: TNF, MTHR, SLC19A1, MTRR, CGH, ABCB1, VNTR, IL1B, IL1RN, KIR2DS2, KIR2DL2, CHST11, AMPD1, ITPA, MTHFD1, FCGR3A, BAFF871, IL-6 oraz genów kodujących białka enzymatyczne uczestniczące w biotransformacji leków: CYP39A1, CYP2D6, CYP1A2, CYP2D6, SLC22A2, SLC7A7, ALDH2 [43-45].

Wskazuje się przykładowo, że polimorfizm genu CYP2D6, odgrywającego ważną rolę w łuszczycy [46], determinuje szybkość metabolizowania leków. Tym samym osoby charakteryzujące się niskim tempem metabolizowania leków, w którym uczestniczy CYP2D6, w większym stopniu są narażone na działania niepożądane terapii ze względu na wydłużony okres dużego 
od of the drug's high serum concentration. Then, extensive metabolizers also require dose modifications since present drug dose regimens fail to correspond with the metabolizing speed [47].

However Gallo et al. highlight the role of polymorphism and mutual dependency between TNF and IL-12/23 in projecting the response to anti-TNF treatment [48]. An expected effect of the therapy with TNF inhibitors depends also on TNFAIP3 genotype, among others [49]. Observations of Warren et al. show no influence of polymorphism of genes participating is methotrexate metabolism. It indicated that not every gene associated with biotransformation of a given drug or polymorphism of a gene against which the treatment is targeted determines the treatment efficacy and enforces an individual therapeutic plan [50].

The development of personalized medicine, i.e. "right drug for the right patient at the right time", was possible thanks to a more in-depth understanding of molecular background of diseases, typing of e.g. cytokines and growth factors, whose change in the expression profile significantly determines the way of effective treatment. Taking into account lesion intensity, molecular background, pharmacokinetics and pharmacogenomics while choosing a therapy against psoriasis allows for choosing biological treatment for a given patient [51]

Studies conducted by Kim et al. show the value of determining the ratio of CD4+ lymphocyte number and lymphocytes B in every psoriatic patient. They show that every patient has their own unique profile of mononuclear blood cells that determined the treatment efficacy. They observed that there is a high risk of no adequate response to treatment in psoriatic patients characterized by a small percentage of CD4+ T-lymphocytes as compared with B-lymphocytes [52].

Miyagawa et al. also emphasize the value of analysis of the pattern of mononuclear blood cells while choosing the therapy involving biological drugs. Given that criterion, ustekinumab was recommended for patients in whom the highest percentage of Th1 phenotype T-lymphocytes was observed; secukinumab for patients in whom a response induced by Th17 lymphocytes dominated; secukinumab or TNF inhibitor for patients with a high percentage of Th1/Th17 lymphocytes, and TNF inhibitor for patients with a low Th1/Th17 index. They came to a conclusion that the choice of the right biological drug and consideration of phenotypical difference $d$ of T-helper lymphocytes caused an increase in therapy efficacy as compared with the treatment chosen without the mentioned criterion [53].

An analysis of molecular background of psoriasis allowed for indicating new supplementary molecular markers associated with the level of disease intensity and response to treatment. Flisiak et al. suggest that assessing gene expression patterns of TGF- $\beta 1$, tissue stężenia leku w surowicy. Szybcy metabolizerzy również wymagają modyfikacji dawki, gdyż obowiązujące schematy dawkowania leków są w ich przypadku nieadekwatne do tempa ich metabolizowania [47].

Natomiast Gallo i wsp. podkreślają udział polimorfizmu i wzajemnej zależności między TNF a IL-12/23 w przewidywaniu odpowiedzi na leczenie anty-TNF [48]. Oczekiwany skutek terapii inhibitorami TNF zależy również m.in. od genotypu TNFAIP3 [49]. Obserwacje Warrena i wsp. wskazują na brak wpływu polimorfizmu genów uczestniczących w metabolizmie metotreksatu. Oznacza to, że nie każdy gen związany z biotransformacją danego leku lub też polimorfizm genu, na który nakierowane jest leczenie, determinuje jego skuteczność i wymusza opracowywanie indywidualnych planów terapii [50].

Rozwój medycyny spersonalizowanej, czyli „,właściwy lek dla właściwego chorego we właściwym czasie”, stał się możliwy dzięki dokładniejszemu zrozumieniu molekularnego podłoża chorób, wytypowaniu np. cytokin, czynników wzrostu, których zmiana profilu ekspresji istotnie determinuje skuteczność leczenia. Uwzględnienie przy doborze terapii łuszczycy nasilenia zmian, ich podłoża molekularnego, jak również farmakogenetyki i farmakogenomiki umożliwia dobór leczenia biologicznego dla danego pacjenta [51].

Badania Kim i wsp. wskazują na wartość określania u każdego pacjenta z łuszczycą stosunku liczby limfocytów CD4+ do limfocytów B. Twierdzą oni, że każdy pacjent ma własny, unikatowy profil jednojądrzastych komórek krwi, który determinuje efektywność terapii. Zaobserwowali, że u pacjentów z łuszczycą charakteryzujących się niewielkim odsetkiem limfocytów T CD4+ w porównaniu z limfocytami B ryzyko braku adekwatnej odpowiedzi na leczenie jest wysokie [52].

Miyagawa i wsp. również podkreślają wartość analizy wzoru jednojądrzastych komórek krwi przy doborze terapii biologicznej. Według tego kryterium ustekinumab został zarekomendowany pacjentom, u których zaobserwowano największy odsetek limfocytów T o fenotypie Th1; sekukinumab pacjentom, u których przeważała odpowiedź indukowana przez limfocyty Th17, a sekukinumab lub inhibitor TNF pacjentom z wysokim odsetkiem limfocytów Th1/Th17 oraz inhibitor TNF pacjentom z niskim wskaźnikiem Th1/Th17. Stwierdzają oni, że wybór odpowiedniego leku biologicznego z uwzględnieniem różnic fenotypowych limfocytów T pomocniczych powodował zwiększenie efektywności terapii w porównaniu z leczeniem dobieranym bez wspomnianego kryterium [53].

Analiza molekularnego podłoża łuszczycy pozwoliła wskazać nowe, uzupełniające markery molekularne związane ze stopniem nasilenia choroby oraz odpowiedzią na leczenie. Flisiak i wsp. sugerują, że ocena wzorców ekspresji TGF- $\beta 1$, tkankowych inhibitorów metaloproteinazy 1 (TIMP-1), metaloproteinazy macie- 
inhibitor of metalloproteinase 1 (TIMP-1), matrix metalloproteinase-1 (MMP-1), and interleukin 18 (IL-18) allows for making conclusions about the lesion advancement level and indicating a predicted level of response to treatment $[54,55]$.

Solberg et al. determined a potential occurrence of individual dependencies between concentration of chosen cytokines in serum of 40 psoriatic patients before and after biological treatment and PASI as well as DLQI. They observed a decrease in PASI values with $71 \%$ and DLQI with $65 \%$, and with regard to molecular profile they observed that an increase in expression (IL-2) is associated with a decrease in PASI and DLQI, whereas an increase in IL-5, IL-10, IL-12, IL-22 and GM-CSF correlated with a positive treatment effect. Moreover, they concluded that an increase in IL-17A level even with $1 \mathrm{pg} / \mathrm{ml}$ predisposed for severe psoriasis [56]. Also, Fitz et al. drew attention to the value of assessing IL-17 expression profile in psoriatic patients before commencing an anti-cytokine therapy [57].

Therefore, it seems that individual genetic profiling of psoriatic patients allows for introducing a more effective form of treatment.

\section{CONCLUSIONS}

Treatment of psoriasis is based of rebuilding the epidermal barrier, limiting inflammation, combating superinfections, and eliminating environmental factors that may exacerbate the disease. Biological drugs used in psoriasis therapy, i.e. etanercept, adalimumab, infliximab, certolizumab pegol, golimumab, secukinumab, ixekizumab, brodalumab, and ustekinumab, are highly effective and exert a positive influence on the quality of live of psoriatic patients.

Modern biological drugs, apart from being highly effective, also have a high safety profile. The following factors may exert a negative influence on the efficacy of psoriasis treatment: genetic factors, environmental factors, bacterial or viral infections, pharmacological and pharmacokinetic interactions associated with additional drugs that a patient takes, pregnancy, metabolic disorders such as diabetes and hypercholesterolemia, heart diseases including arterial hypertension, bad eating habits, lifestyle, excessive alcohol consumption, excessive smoking, and mental condition.

Due to a relatively large number, diversity and co-existence of these factors, it is necessary to take them into account while panning therapeutic strategies against psoriasis.

\section{CONFLICT OF INTEREST}

The authors declare no conflict of interest. rzy 1 (MMP-1) i IL-18 umożliwia wnioskowanie o stopniu zaawansowania zmian i wskazuje przewidywaną odpowiedź na leczenie [54,55].

Solberg i wsp. badali potencjalne indywidualne zależności pomiędzy stężeniem wybranych cytokin w surowicy 40 pacjentów z łuszczycą przed otrzymaniem i po otrzymaniu leczenia biologicznego a wskaźnikami PASI i DLQI. Zaobserwowali zmniejszenie wartości PASI o 71\% i DLQI o 65\%, a w odniesieniu do profilu molekularnego stwierdzili, że wzrost ekspresji IL-2 wiąże się z obniżeniem wartości PASI i DLQI, natomiast wzrost stężenia IL-5, IL-10, IL-12, IL-22 i GM-CSF koreluje z pozytywnym efektem leczenia. Ponadto stwierdzili, że wzrost poziomu IL-17A już o 1 pg/ml predysponował do wystąpienia łuszczycy o ciężkim nasileniu [56]. Również Fitz i wsp. zwrócili uwagę na znaczenie określania profilu ekspresji IL-17 u pacjentów z łuszczycą przed rozpoczęciem terapii antycytokinowej [57].

Wydaje się, że indywidualne profilowanie genetyczne pacjentów z łuszczycą pozwala wdrażać bardziej skuteczne leczenie.

\section{PODSUMOWANIE}

Leczenie łuszczycy polega na odbudowie bariery naskórkowej, ograniczeniu stanu zapalnego, zwalczaniu nadkażeń oraz eliminacji czynników środowiskowych, które mogą zaostrzać przebieg choroby. Leki biologiczne stosowane w terapii łuszczycy: etanercept, adalimumab, infliksymab, certolizumab pegol, golimumab, sekukinumab, iksekizumab, brodalumab oraz ustekinumab - mają wysoką skuteczność oraz pozytywny wpływ na jakość życia chorych.

Współczesne leki biologiczne, oprócz dużej skuteczności, cechują się dobrym profilem bezpieczeństwa. Na efektywność terapii łuszczycy wpływają: czynniki genetyczne, czynniki środowiskowe, infekcje bakteryjne i wirusowe, interakcje farmakologiczno-farmakokinetyczne dodatkowo przyjmowanych leków, ciąża, zaburzenia metaboliczne, takie jak cukrzyca, hipercholesterolemia, choroby serca (m.in. nadciśnienie tętnicze), nieodpowiednie nawyki żywieniowe, tryb życia, spożywanie nadmiernych ilości alkoholu, palenie papierosów, stan psychiczny.

Ze względu na relatywnie dużą liczbę czynników, różnorodność oraz możliwość jednoczesnego udziału kilku konieczne jest uwzględnianie ich roli przy planowaniu strategii terapii łuszczycy.

\section{KONFLIKT INTERESÓW}

Autorzy nie zgłaszają konfliktu interesów. 
References

Piśmiennictwo

1. Szepietowski J., Adamski Z., Chodorowska G., Kaszuba A., Placek W., Rudnicka L., et al.: Leczenie łuszczycy - rekomendacje ekspertów Polskiego Towarzystwa Dermatologicznego. Część II: łuszczyca umiarkowana do ciężkiej. Przegl Dermatol 2014, 101, 455-472.

2. Spuls P., Lecluse L., Poulsen M.: How good are clinical severity and outcome measures for psoriasis? Quantitative evaluation in a systematic review. J Invest Dermatol 2010, 130, 933-943.

3. Liluashvili S., Kituashvili T.: Dermatology Life Quality Index and disease coping strategies in psoriasis patients. Adv Dermatol Allergol 2019, 36, 419-424.

4. Kim W.B., Jerome D., Yeung J.: Diagnosis and management of psoriasis. Can Fam Physician 2017, 63, 278-285.

5. Calautti E., Avalle L., Poli V.: Psoriasis: a STAT3-centric view. Int J Mol Sci 2018, 19, 171.

6. Menter A., Gottlieb C.A., Feldman S.R., Van Voorhees A.S., Leonardi C.L., Gordon K.B., et al.: Guidelines of care for the management of psoriasis and psoriatic arthritis: section 1. Overview of psoriasis and guidelines of care for the treatment of psoriasis with biologics. J Am Acad Dermatol 2008, 58, 826-850.

7. Wcisło-Dziadecka D., Grabarek B., Zmarzły N., Skubis A., Sikora B., Kruszniewska-Rajs C., et al.: Influence of adalimumab on the expression profile of genes associated with the histaminergic system in the skin fibroblasts in vitro. Biomed Res Int 2018, 2018, 1582173.

8. Grabarek B., Wcislo-Dziadecka D., Gola J., Kruszniewska-Rajs C., Brzezinska-Wcislo L., Zmarzly N., et al.: Changes in the expression profile of Jak/Stat signaling pathway genes and miRNAs regulating their expression under the adalimumab therapy. Curr Pharm Biotechnol. 2018, 19, 556-565.

9. Jalah R., Rosati M., Ganneru B., Pilkington G.R., Valentin A., Kulkarni V., et al.: The p40 subunit of interleukin (IL)-12 promotes stabilization and export of the p35 subunit. J Biol Chem 2013, 288, 6763-6776.

10. Nestle F.O., Kaplan D.H., Barker J.: Łuszczyca i schorzenia pokrewne. N Engl J Med 2009, 361, 496-509.

11. Amatya N., Garg A.V., Gaffen S.L.: IL-17 Signaling: the Yin and the Yang. Trends Immunol 2017, 38, 310-322.

12. Simone C., Caldarola G., Maiorino A.: Clinical predictors of nonresponse to anti-TNF-alpha agents in psoriatic patients: a retrospective study. Dermatol Ther 2016, 29, 372-376.

13. Brenner D., Blaster H., Mak T.W.: Regulation of tumour necrosis factor signalling: live or let die. Nat Rev Immunol 2015, 15, 362-374.

14. Chiricozzi A., Romanelli P., Volpe E., Borsellino G., Romanelli M.: Scanning the immunopathogenesis of psoriasis. Int J Mol Sci 2019, 19, E179.

15. Reich A., Szepietowski J., Adamski Z., Chodorowska G., Kaszuba A., Krasowska D., et al.: Łuszczyca. Rekomendacje diagnostyczno-terapeutyczne Polskiego Towarzystwa Dermatologicznego. Część II: łuszczyca umiarkowana do ciężkiej. Dermatol Rev 2018, 105, 329-357.

16. Reich A., Adamski Z., Chodorowska G., Kaszuba A., Krasowska D., Lesiak A.: Łuszczyca. Rekomendacje diagnostyczno-terapeutyczne Polskiego Towarzystwa Dermatologicznego. Część I: łuszczyca łagodna. Dermatol Rev 2018, 105, 225-243.

17. Jaśkiewicz-Nyckowska D., Szczerkowska-Dobosz A., Czubek M., Purzyńska-Bohdan D.: Problemy dotyczące fałszywie dodatnich testów laboratoryjnych podczas kwalifikacji do programu „Leczenia ciężkiej postaci łuszczycy plackowatej” na podstawie dwóch przypadków. Dermatol Rev 2015, 102, 33-36.

18. Kwiek B., Narbutt J., Sysa-Jędrzejowska A., Lagner A., Lesiak A.: Long-term treatment of chronic plaque psoriasis with biological drugs can control platelet activation: targeting the bridge between inflammation and atherothrombosis. Adv Dermatol Allergol 2017, 34, 131-137.

19. Wcisło-Dziadecka D., Grabarek B., Brzezińska-Wcisło L., Mazurek U.: Drug resistance in anti-TNF therapy of psoriatic arthritis. Dermatol Rev 2018, 105, 625-631.

20. Louis M.B.: Are TNF-alpha inhibitors infliximab and certolizumab pegol effective in treating adults with psoriatic arthritis (PsA) or PsA patients who have previously failed disease-modifying anti-rheumatic drug (DMARD) therapy? PCOM 2018, 334.

21. Pranzatelli M.R.: Advances in biomarker-guided therapy for pediatric- and adult-onset neuroinflammatory disorders: targeting chemokines/cytokines. Front Immunol 2018, 9, 557.

22. Le Tourneau C., Kamal M., Tsimberidou A.M., Bedard P., Pierron G., Callens C., et al.: Treatment algorithms based on tumor molecular profiling: the essence of precision medicine trials. J Natl Cancer Inst 2015, 108, 362.

23. Talamonti M., D'Adamio S., Bianchi L., Galluzzo M.: The role of pharmacogenetics in chronic plaque psoriasis: update of the literature. Mol Diag Ther 2017, 21, 467-480.

24. Tsuchida Y., Sumitomo S., Ishigaki K., Suzuki A., Kochi Y., Tsuchiya H.: TGF-beta3 inhibits antibody production by human B cells. PLoS One 2017, 12, e0169646.

25. Zhang J., Shaver C., Neidig L., Jones K., Cusack C.A., Allen H.B.: Toll-like receptor 2 and its relationship with streptococcus in psoriasis. Skinmed 2017, 15, 27-30.

26. Allen H.B., Jadeja S., Allawh R.M., Goyal K.: Psoriasis, chronic tonsillitis, and biofilms: tonsillar pathologic findings supporting a microbial hypothesis. Ear Nose Throat J 2018, 97, 79-82.

27. Romańska-Gocka K.: Farmakoterapia łuszczycy. Farm Pol 2009, 65, 647-654.

28. Mehta N.N., Azfar R.S., Shin D.B., Neimann A.L., Troxel A.B., Gelfand J.M.: Patients with severe psoriasis are at increased risk of cardiovascular mortality: cohort study using the general practice research database. Eur Heart J 2010, 31, 1000-1006.

29. Davidovici B.B., Sattar N., Prinz J.: Psoriasis and systemic inflammatory diseases: potential mechanistic links between skin disease and co-morbid conditions. J Invest Dermatol 2010, 130, 1785-1796.

30. Bardazzi F., Odorici G., Magnano M., Patrizi A., Tengattini V.: Cyclosporine in clinical practice: a retrospective study comparing fixed dose and body weight-based dose regimens in psoriatic patients. G Ital Dermatol Venereol 2018, doi: 10.23736/ S0392-0488.18.05651-1. 
31. Gisondi P., Del Giglio M., Di Francesco V.: Weight loss improves the response of obese patients with moderate-to-severe chronic plaque psoriasis to low-dose cyclosporine therapy: a randomized, controlled, investigator-blinded clinical trial. Am J Clin Nutr 2008, 88, 1242-1247.

32. Ricceri F., Bardazzi F., Chiricozzi A., Dapavo P., Ferrara F., Mugheddu C., et al.: Elderly psoriatic patients under biological therapies: an Italian experience. J Eur Acad Derm Venereol 2019, 33, 143-146.

33. Sarkar R., Narang I.: Atopic dermatitis in Indian children: the influence of lower socioeconomic status. Clin Dermatol 2018, 36, 585-594.

34. Di Lernia V., Goldust, M.: An overview of the efficacy and safety of systemic treatments for psoriasis in the elderly. Expert Opin Biol Ther 2018, 18, 897-903.

35. Choi C.W., Choi J.Y., Kim B.R., Youn S.W.: Economic burden can be the major determining factor resulting in short-term intermittent and repetitive ustekinumab treatment for moderate-to-severe psoriasis. Ann Dermatol 2018, 30, 179-185.

36. Sizto S., Bansback N., Feldman S.R., Willian M.K., Anis A.H.: Economic evaluation of systemic therapies for moderate to severe psoriasis. Br J Dermatol 2009, 160, 1264-1272

37. Augustin M., McBride D., Gilloteau I., O'Neill C., Neidhardt K., Graham C.N.: Cost-effectiveness of secukinumab as first biologic treatment, compared with other biologics, for moderate to severe psoriasis in Germany. J Eur Acad Dermatol Venereol 2018, 32, 2191-2199.

38. Snast I., Reiter O., Atzmony L., Leshem Y.A., Hodak E., Mimouni D., et al.: Psychological stress and psoriasis: a systematic review and meta-analysis. Br J Dermatol 2018, 178, 1044-1055.

39. Kwon C.W., Fried R.G., Nousaric Y., Ritchlin C., Tausk F.: Psoriasis: psychosomatic, somatopsychic, or both? Clin Dermatol 2018, 36, 698-703.

40. Jin W., Zhang S., Duan Y.: Depression symptoms predict worse clinical response to etanercept treatment in psoriasis patients. Dermatology 2019, 235, 55-64.

41. Ford A.R., Siegel M., Bagel J., Cordo K.M., Garg A., Gottlieb A., et al.: Dietary recommendations for adults with psoriasis or psoriatic arthritis from the medical board of the national psoriasis foundation: a systematic review. JAMA Dermatol 2018, 154, 934-950.

42. Ljubenovic M., Lazarevic V., Golubovic M., Binic I.: Integrative approach to psoriasis vulgaris. Holist Nurs Pract 2018, 32, 133-139.

43. Tavakolpour S.M., Ghasemiadl D.M.: Pharmacogenetics: a strategy for personalized medicine for autoimmune diseases. Clin Genet 2018, 93, 481-497.

44. Ovejero-Benito M.C., Muñoz-Aceituno E., Reolid A., Saiz-Rodríguez M., Abad-Santos F., Daudén E.: Pharmacogenetics and pharmacogenomics in moderate-to-severe psoriasis. Am J Clin Dermatol 2018, 19, 209-222.

45. Storelli F., Samer C., Reny J.L., Desmeules J., Daali Y.: Complex drug-drug-gene-disease interactions involving cytochromes P450: systematic review of published case reports and clinical perspectives. Clin Pharmacokinet 2018, 57, 1267-1293.

46. Rychlik-Sych M., Barańska M., Skrętowicz J.: Clinical significance of pharmacogenetics in dermatological diseases. Przegl Lek 2012, 69, 120-124.

47. Wilkinson G.R.: Drug metabolism and variability among patients in drug response. N Engl J Med 2005, 352, $2211-2221$.

48. Gallo E., Cabaleiro T., Román M., Solano-López G., Abad-Santos F., García-Díez A., et al.: The relationship between tumour necrosis factor (TNF)-alpha promoter and IL12B/IL-23R genes polymorphisms and the efficacy of anti-TNF-alpha therapy in psoriasis: a case-control study. Br J Dermatol 2013, 169, 819-829.

49. Tejasvi T., Stuart P.E., Chandran V., Voorhees J.J., Gladman D.D., Rahman P., et al.: TNFAIP3 gene polymorphisms are associated with response to TNF blockade in psoriasis. J Invest Dermatol 2012, 132, 593-600.

50. Warren R.B., Smith R.L., Campalani E., Eyre S., Smith C.H., Barker J.N.W.N., et al.: Outcomes of methotrexate therapy for psoriasis and relationship to genetic polymorphisms. Br J Dermatol 2009, 160, 438-441.

51. Evans W.E., McLeod H.L.: Pharmacogenomics - drug disposition, drug targets, and side effects. N Engl J Med 2003, 348, 538-549.

52. Hernández-Breijo B., Jurado T., Rodríguez-Martín E., Martínez-Feito A., Plasencia-Rodríguez C., Balsa A., et al.: Differential blood cellular profile in patients with moderate-to-severe psoriasis treated with classical systemic therapies: a step forward in personalized medicine. Br J Dermatol 2018, 179, 765-766.

53. Miyagawa I., Nakayamada S., Nakano K., Kubo S., Iwata S., Miyazaki Y., et al.: Precision medicine using different biological dmards based on characteristic phenotypes of peripheral T helper cells in psoriatic arthritis. BMJ 2018, 77, $206-207$.

54. Flisiak I., Porebski P., Chodynicka B.: Effect of psoriasis activity on metalloproteinase-1 and tissue inhibitor of metalloproteinase-1 in plasma and lesional scales. Acta Derm Venereol 2006, 86, 17-21.

55. Flisiak I., Klepacki A., Chodynicka B.: Plasma and scales levels of interleukin 18 in comparison with other possible clinical and laboratory biomarkers of psoriasis activity. Biomarkers 2006, 11, 194-200.

56. Solberg S.M., Sandvik L.F., Eidsheim M., Jonsson R., Bryceson Y.T., Appel S.: Serum cytokine measurements and biological therapy of psoriasis - prospects for personalized treatment? Scand J Immunol 2018, 88, e12725.

57. Fitz L., Zhang W., Soderstrom C., Fraser S., Lee J., Quazi A., et al.: Association between serum interleukin-17A and clinical response to tofacitinib and etanercept in moderate to severe psoriasis. Clin Exp Dermatol 2018, 43, $790-797$.

Received: 1.12 .2018

Accepted: 30.03 .2019

Otrzymano: $1.12 .2018 \mathrm{r}$.

Zaakceptowano: 30.03.2019 r.

How to cite this article

Grabarek B.O., Krzaczyński J., Strzałka-Mrozik B., Wcisło-Dziadecka D.: An analysis of selected factors influencing the efficacy of psoriasis therapy. Dermatol Rev/Przegl Dermatol 2019, 106, 603-614. DOI: https://doi.org/10.5114/dr.2019.92733. 